\title{
ŠTRUKTÚRA PROFESIJNÝCH ZÁUJMOV SLOVENSKÝCH ŽIAKOV ZÁKLADNÝCH ŠKÔL NA BÁZE MODELOV RIASEC
}

\author{
Marcel Martončik, Monika Kačmárová
}

\begin{abstract}
Abstrakt
Ciel'om štúdie bolo overit' platnost' troch štruktúrnych modelov profesijných záujmov konceptu RIASEC u slovenských žiakov základných škôl. Overované boli Hollandov kruhový model, Gatiho hierarchický model a Roundsov a Traceyho modifikovaný hierarchický model. Predpoklady, ktoré z týchto modelov vyplývajú, boli testované pomocou Hubertovho a Arabieho randomizačného testu hypotetických poradí a multidimenzionálneho škálovania. Výskumu sa zúčastnilo 400 žiakov 8. - 9. ročníka základných škôl $(\mathrm{M}=14$ rokov; $\mathrm{SD}=1)$, ktorým bol administrovaný Dotazník štruktúry všeobecných záujmov (DŠVZ). Štruktúru záujmov slovenských žiakov najlepšie vysvetlil kruhový model Hollanda. Diskutované sú i implikácie pre použitie dotazníka DŠVZ v praxi.
\end{abstract}

Klúčové slová: profesijné záujmy, štruktúra záujmov, RIASEC, Hollandova teória, hexagonálny model

STRUCTURE OF VOCATIONAL INTERESTS IN SLOVAK ELEMENTARY SCHOOL PUPILS BASED ON RIASEC MODELS

\begin{abstract}
The goal of the study was to verify the validity of three RIASEC models of the structure of vocational interests in Slovak elementary school pupils. Verified models were the Holland's circular model, the Gati's hierarchical model, and the Rounds and Tracey's modified hierarchical model. The assumptions from these models were tested using the Hubert and Arabie's randomization test of hypothetical orders and multidimensional scaling. The sample consisted of 400 pupils from 8th to 9th grade attending primary school $(M=14$ years, $S D=1)$, who were administered a questionnaire Dotazník štruktúry všeobecných záujmov $(D S ̌ V)$. The structure of vocational interests of Slovak pupils was best explained by the Holland's circular model. Implications for using the questionnaire DŠVZ in practice are also discussed.
\end{abstract}

Key words: vocational interests, structure of interests, RIASEC, Holland's theory, hexagonal model.

Došlo do redakce: 25.1 .2018

Schváleno k publikaci: 6. 8. 2018 


\section{Úvod}

Hlavným poskytovatel'om kariérového poradenstva v Slovenskej republike sú Centrá pedagogického a psychologického poradenstva a prevencie. Až $35 \%$ ich klientov sem prichádza práve za účelom kariérového poradenstva (Machajová \& Sojčák, 2011). Jeho podstatnou súčast'ou je aj zist'ovanie profesijných záujmov, ktoré je obzvlášt' aktuálne a potrebné u žiakov končiacich ročníkov základných škôl počas ich prvej smerovej vol'by, kedy sa rozhodujú o výbere študijného odboru a typu strednej školy. V tomto období často vyhl'adávajú pomoc bud' kariérového poradcu, alebo psychológa. Tí k zist'ovaniu profesijných záujmov najčastejšie používajú Test hierarchie záujmov, interaktívne informačno-poradenské programy Sprievodca svetom povolaní a Cesta k povolaniu alebo dotazník Základné stredoškolské zameranie (Prieskum metodík zist'ovania profesijných záujmov, n.d.). Problémom uvedených metodík je to, že sú bud' zastaralé, ateoretické alebo nevalidované. $\mathrm{Z}$ toho dôvodu je vel'mi žiaduce, aby profesionáli v praxi pracovali s validnými a teoreticky podloženými diagnostickými nástrojmi. Dotazníky profesijných záujmov by preto mali vychádzat' z takej teórie štruktúry profesijných záujmov, ktorej platnost' bola overená na populácii, pre ktorú bude dotazník určený.

\section{Teoretické východiská}

Poznanie štruktúry záujmov je podl'a Roundsa a Dayovej (1999) dôležité pre identifikáciu kategórií záujmov a pri poznávaní vzt’ahov medzi týmito kategóriami. Štruktúra záujmov zohráva dôležitú úlohu aj v teóriách zhody medzi pracovným prostredím a osobou, ktoré sa snažia kategorizovat' l'udí a prostredie. Ak je do pracovného prostredia zaradená osoba s komplementárnymi schopnost'ami, zručnost’ami či vlastnost'ami, existuje predpoklad, že bude dosahovat' vyšší výkon, stabilitu a spokojnost' v zamestnaní. Najznámejšia kategorizácia záujmov, ktorej autorom je Holland (1997), je tvorená šiestimi záujmovými typmi známymi aj po skratkou RIASEC. Existuje niekol'ko štruktúrnych modelov, ktoré vysvetl'ujú vzt'ahy medzi jednotlivými kategóriami RIASEC. Ďalej v texte budú predstavené tri najvýznamnejšie štruktúrne modely RIASEC: Hollandov (1997) kruhový model, Gatiho (1979) hierarchický model a Roundsov a Traceyho (1996) modifikovaný hierarchický model.

Hollandov model RIASEC je pravdepodobne najznámejším modelom štruktúry profesijných záujmov (Holland, 1973, 1997), a zároveň aj prevládajúcim modelom, ktorý predstavuje východisko pri konštruovaní záujmových dotazníkov (Gottfredson \& Holland, 1996, in Holland \& Messer, 2013; Savickas \& Gottfredson, 1999). Holland (1997) opisuje svoju teóriu ako osobnostnú, a rovnako tak aj záujmové dotazníky nazýva osobnostnými dotazníkmi, ked’že profesijné záujmy sú dôležitým aspektom osobnosti. Šest' písmen v akronyme RIASEC vyjadruje šest' typov osobnosti a šest' typov prostredia, ktoré sú teóriou postulované: $\mathrm{R}$ pre praktický typ, I pre intelektuálny typ, A pre umelecký typ, S pre sociálny typ, E pre podnikatel'ský typ a C pre konvenčný typ. Osobnostný typ ako osobnostná dispozícia usmerňuje osobu mysliet', vnímat' a konat' určitým špecifickým spôsobom. Pre každý zo šiestich osobnostných typov sú typické odlišné záujmy, schopnosti, preferované aktivity a profesie, hodnoty, zvládacie štýly či sebakoncept, preto „napr. osoby, ktoré sa viac podobajú sociálnemu typu, budú pravdepodobne častejšie vyhl'adávat' sociálne profesie, ako napr. učitel'stvo či sociálnu prácu. Seba budú pravdepodobne považovat' za priatel'ské a spoločenské osoby s rozvinutými sociálnymi kompetenciami (napr. pomáhanie iným s ich 
osobnými problémami) než praktickými kompetenciami (napr. používanie nástrojov alebo chápanie fungovania strojov)“ (Holland, 1997, s. 2). Č́́m viac sa osoba podobá konkrétnemu typu, tým jej bude patrit' viac osobnostných vlastností a prejavov správania typických pre daný typ.

Hollandov model sa často zvykne označovat' nielen ako model RIASEC, ale aj ako hexagonálny model. Toto označenie sa vzt’ahuje k priestorovému usporiadaniu osobnostných typov, ktoré Holland (1997) vyjadril pomocou šest'uholníka. Usporiadanie typov v šest'uholníku je presne dané a vyjadruje vzájomné vzt’ahy medzi jednotlivými typmi, ktoré sú nepriamo úmerné tesnosti teoretických vzt’ahov medzi nimi. Čím bližšie k sebe sú dva typy umiestnené, tým väčšia je ich vzájomná podobnost'. Ako poznamenali Tracey a Rounds (1993), hexagonálny model je možné stotožnit' s kruhovým modelom (circular ordering), pretože jednotlivé osobnostné typy sú v rámci obidvoch modelov usporiadané rovnako. Holland (1997) je zároveň autorom najpoužívanejšieho záujmového dotazníka v histórii vychádzajúceho z koncepcie osobnostných typov RIASEC, dotazníka Self-Directed Search (Spokane \& Holland, 1995).

Len niekol'ko rokov po Hollandovom (1973) predstavení vlastnej teórie navrhol Gati (1979) alternatívny Hierarchický model. Ten mal prekonávat' Hollandov model lepším vysvetlením vzt’ahov medzi typmi RIASEC. Tie usporadúva do delenia na tri klastre: (R, I), (A, S), (E, C). V Gatiho $(1979,1991)$ modeli je klasifikácia záujmov usporiadaná do niekol'kých úrovní. Na najvyššej úrovni sú dve hlavné skupiny záujmov, tzv. mäkká veda a tvrdá veda, ktoré sa v nižších úrovniach rozvetvujú. Každá vetva obsahuje určitý počet tzv. profesijných polí, teda klastrov relatívne podobných profesií, a pokračuje v delení na d'alšie vetvy. Gati (1991) ponúka na rozdiel od jednokrokovej klasifikácie hexagonálneho modelu Hollanda viac krokovú klasifikáciu začínajúcu s niekol'kými hlavnými klastrami, založenými na primárnych rozdieloch povolaní a pokračujúcu klastrami so špecifickejšími rozdielmi, založenými na menej významných rozdieloch medzi povolaniami.

Podl'a Roundsa a Traceyho (1996) je hlavným problémom Hollandovho i Gatiho modelu sila vzt’ahu medzi typmi A a S. Obidva modely ich považujú za príbuzné. Uvedení autori citujú výskumy (Fouad \& Dancer, 1992; Swanson, 1992; Tracey \& Rounds, 1993), ktoré túto príbuznost' nepotvrdili. Vzhl'adom k tomu navrhli úpravu Gatiho modelu, v ktorom typ A tvorí samostatnú kategóriu (RI, A, SEC).

Ciel'om tejto štúdie exploračného charakteru bolo určit', či je možné niektorým z troch známych šest'faktorových záujmových modelov RIASEC (Holland, 1997; Gati, 1979; Rounds \& Tracey, 1996) vysvetlit' štruktúru profesijných záujmov žiakov končiacich ročníkov základných škôl. Z najznámejšej a teoreticky najsilnejšej Hollandovej (1997) teórie sa v domácom prostredí používa pre výskumné účely k meraniu profesijných záujmov iba Dotazník štruktúry všeobecných záujmov (Džuka, 1999). Doteraz však neboli publikované dôkazy o tom, že použitie Hollandovej teórie RIASEC je vdomácich podmienkach opodstatnené, ked’že Hollandova teória bola koncipovaná a validovaná v kultúre bielych Severoameričanov. 


\section{METÓDA}

\section{Vzorka}

Vzorku tvorilo 400 žiakov končiacich ročníkov základných škôl z východného Slovenska, z čoho 182 žiakov navštevovalo 8. ročník a 218 žiakov 9. ročník. Z celkového počtu žiakov bolo 205 chlapcov a 195 dievčat. Priemerný vek bol 14 rokov $(S D=1)$. Vzorka bola vyberaná nenáhodným spôsobom, avšak pri výbere bola proporcionálne zohl'adnená vel'kost' bydliska podl'a počtu obyvatel'ov.

\section{Výskumný nástroj}

Dotazník štruktúry všeobecných záujmov (DŠVZ) (Džuka, 1999) predstavuje slovenskú adaptáciu dotazníka Der Allgemeine Interessen-Struktur-Test, AIST, od autorov (Bergmann \& Eder, 1992, in Džuka, 1999). Pozostáva zo 60 položiek, 10 položiek pre každú dimenziu modelu RIASEC. Respondent vyjadruje mieru svojho záujmu na škále od 1 (vôbec ma to nezaujíma/nerád to robím) do 5 (vel'mi ma to zaujíma/vel'mi rád to robím).

Reliability pre jednotlivé subškály modelu RIASEC boli nasledovné: R) .84, 95 \% CI [.81, $.86]$; I) $.85,95 \%$ CI $[.82, .88]$; A) $.87,95 \%$ CI $[.85, .89]$; S) $.85,95 \%$ CI $[.83, .87]$; E) .85, $95 \%$ CI $[.83, .87] ;$ C) $.82,95 \%$ CI $[.79, .85]$.

\section{Štatistické spracovanie údajov}

$\mathrm{Z}$ celkového počtu údajov bolo chýbajúcich iba $0.19 \%$ odpovedí a tieto chýbajúce údaje boli nahradené pomocou metódy Expectation-Maximization (EM). Hodnoty reliability vyjadrené koeficientom omega total (Dunn, Baguley, \& Brunsden, 2014) boli počítané v programe R verzii 3.3.2 ( $\mathrm{R}$ Core Team, 2017).

Pre exaktné testovanie zhody údajov s usporiadaním záujmových typov postulovaných Hollandom (1997), Gatim (1979) a Roundsom a Traceym (1996) bol použitý randomizačný test hypotetických poradí ,randomization test of hypothetical orders“ (RTOR, Hubert \& Arabie, 1987; Rounds, Tracey, \& Hubert, 1992; Tracey, 1997). RTOR pracuje s korelačnou maticou a údajmi o relatívnom poradí vel'kostí korelácí́. Deskriptívnou štatistikou, ktorá vyjadruje mieru zhody medzi údajmi a modelom, je index zhody (correspondence index, CI). Počíta sa ako rozdiel medzi správnymi a nesprávnymi predikciami vzt’ahujúcimi sa k poradiu vel'kostí korelácií vydelenými celkovým počtom predikcií. Index zhody môže nadobúdat' hodnoty od -1 do 1 , kde vyššia hodnota vyjadruje lepší model fit. RTOR bol počítaný funkciami RANDALL a RANDMF upravenými do programovacieho jazyka R, verzie 3.4.1 (R Core Team, 2017) s využitím knižnice ,permute“.

Pre zobrazenie priestorového usporiadania štruktúry profesijných záujmov v podobe typov RIASEC bolo použité multidimenzionálne škálovanie $\mathrm{s}$ algoritmom ALSCAL programu SPSS 21 s modelom Euklidovských vzdialeností. Model fit bol overovaný pomocou Kruskalovej stresovej hodnoty (Stress value), ktorá môže nadobúdat' hodnoty od 0 do 1 , kde 1 reprezentuje vynikajúci model fit. 


\section{Výsledky}

V tabul'ke 1 sú uvedené priemerné hodnoty a smerodajné odchýlky subškál RIASEC dotazníka DŠVZ vzhl'adom k pohlaviu respondentov.

Tabul'ka 1 Priemerné hodnoty a smerodajné odchýlky profesijných záujmov vzhl'adom $\mathrm{k}$ pohlaviu $(\mathrm{N}=400)$

\begin{tabular}{ccccccc}
\hline & \multicolumn{2}{c}{ Chlapci $(\mathrm{n}=205)$} & & \multicolumn{2}{c}{ Dievčatá $(\mathrm{n}=195)$} & \\
\cline { 2 - 3 } & $\mathrm{M}$ & $\mathrm{SD}$ & & $\mathrm{M}$ & $\mathrm{SD}$ & t-hodnota \\
\hline $\mathbf{R}$ & 2.60 & .76 & & 1.65 & .49 & $14.94^{* * *}$ \\
$\mathbf{I}$ & 2.40 & .86 & & 2.17 & .77 & $2.74^{* *}$ \\
$\mathbf{A}$ & 1.78 & .65 & & 2.53 & .87 & $-9.66^{* *}$ \\
$\mathbf{S}$ & 2.17 & .69 & & 2.96 & .81 & $-10.43^{* *}$ \\
$\mathbf{E}$ & 2.40 & .81 & & 2.60 & .85 & $-2.42^{*}$ \\
$\mathbf{C}$ & 2.09 & .71 & & 1.95 & .67 & $2.07^{*}$ \\
\hline
\end{tabular}

Poznámka: ${ }^{*}=\mathrm{p}<.05 ;{ }^{* *}=\mathrm{p}<.01$

V type $\mathrm{R}$ ( $\left.\mathrm{g}_{\text {Hedges }}=-1.47\right)$, I ( $\left.\mathrm{g}_{\text {Hedges }}=-.28\right)$ a C $\left(\mathrm{g}_{\text {Hedges }}=-.20\right)$ dosiahli signifikantne vyššie skóre chlapci a $\mathrm{v}$ typoch $\mathrm{A}\left(\mathrm{g}_{\text {Hedges }}=.98\right), \mathrm{S}\left(\mathrm{g}_{\text {Hedges }}=1.05\right)$ a $\mathrm{E}\left(\mathrm{g}_{\text {Hedges }}=.24\right)$ dosiahli signifikantne vyššie skóre dievčatá.

Pomocou metódy RTOR bola overovaná platnost' Hollandovho (1997), Gatiho (1979) a Roundsa a Traceyho (1996) modelu na získané dáta. Výsledky pre celú vzorku a pre jednotlivé pohlavia sú uvedené v tabul'ke 2.

Tabul'ka 2 Výsledky randomizačného testu hypotetických poradí troch testovaných modelov

\begin{tabular}{lccc}
\hline \multicolumn{1}{c}{ Model } & $\begin{array}{c}\text { Celá vzorka } \\
(\mathrm{N}=400)\end{array}$ & $\begin{array}{c}\text { Dievčatá } \\
(\mathrm{n}=195)\end{array}$ & $\begin{array}{c}\text { Chlapci } \\
(\mathrm{n}=205)\end{array}$ \\
\hline Holland (1997) & & & 72 \\
Počet predikcií v modeli & 72 & 72 & 49 \\
Počet splnených predikcí́ & 59 & 68 & .375 \\
$\mathrm{CI}$ & .638 & .888 & .033 \\
$\mathrm{p}$ & .033 & .016 & 36 \\
Gati (1979) & & & 25 \\
Počet predikcií v modeli & 36 & 36 & .416 \\
Počet splnených predikcí́ & 34 & 34 & .066 \\
CI & .888 & .888 & 44 \\
$\mathrm{p}$ & .066 & .066 & 35 \\
Rounds \& Tracey (1996) & & 44 & .613 \\
Počet predikcií v modeli & 44 & 39 & .050 \\
Počet splnených predikcií & 35 & .772 & .016 \\
CI & .590 & .116 & \\
$\mathrm{p}$ & & &
\end{tabular}


$\mathrm{Z}$ troch testovaných modelov vykázal najvyššiu mieru zhody s údajmi Hollandov model (1997) so signifikantným CI $=$.638. Štruktúru záujmov dievčat by bolo možné vysvetlit' okrem Hollandovho modelu aj pomocou modelu Roundsa a Traceyho, hoci s menšou mierou presnosti.

Priestorové usporiadanie jednotlivých typov RIASEC bolo overované aj pomocou techniky multidimenzionálneho škálovania. V grafe 1 je znázornená dvojrozmerná konfigurácia údajov získaných zo subškál dotazníka DŠVZ. Kruskalova stresová hodnota bola .097 a RSQ bolo .926. Kruskal (in Wagenaar \& Padmos, 1971) uvádza, že hodnoty menšie ako .10 znamenajú dobrú zhodu s údajmi (adequate fit).

Graf 1: Dvojdimenzionálne priestorové usporiadanie typov RIASEC v celej vzorke

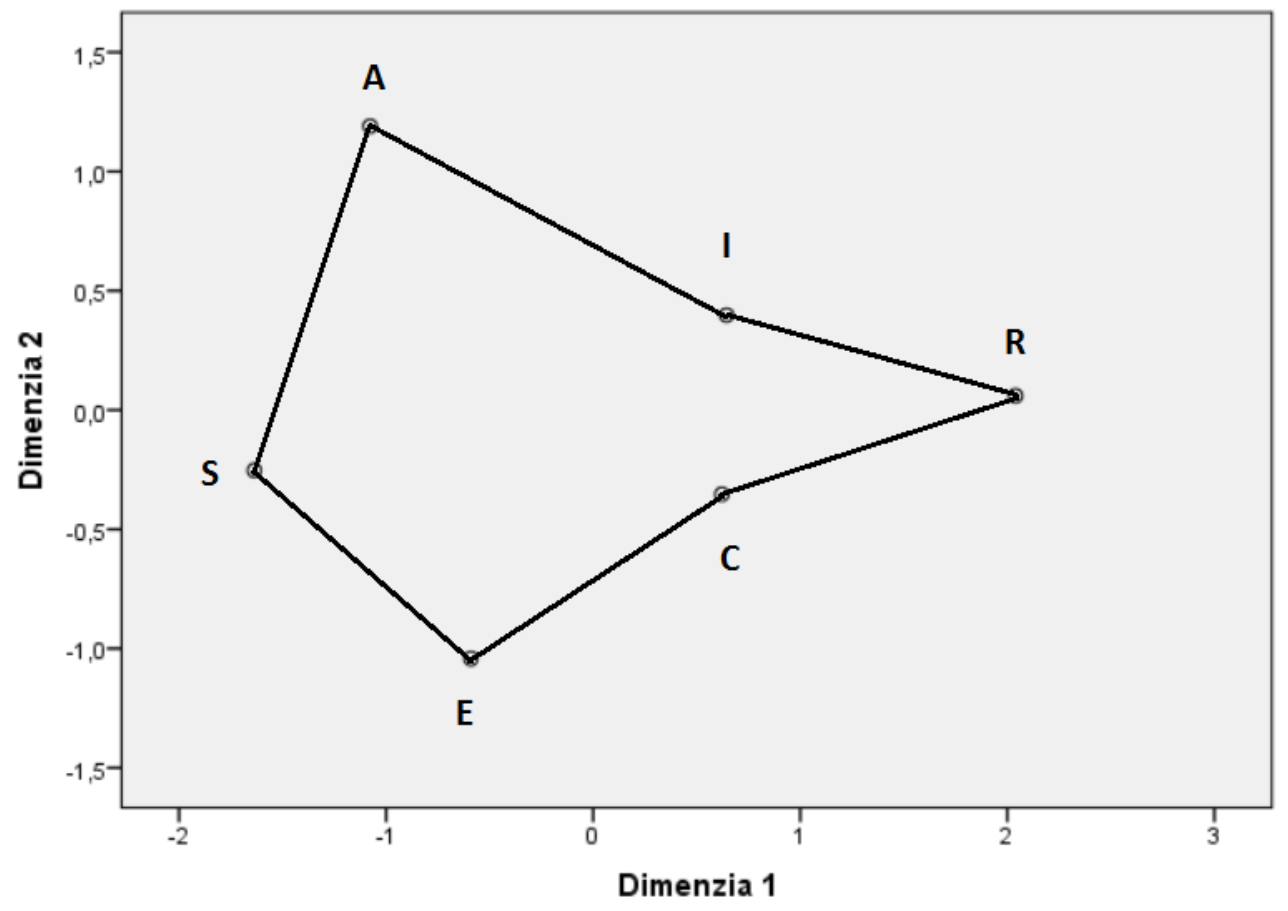

Pozorované multidimenzionálne škálované riešenie síce neaproximovalo $\mathrm{k}$ hexagonálnemu usporiadaniu avšak aproximovalo ku kruhovému priestorovému usporiadaniu typov RIASEC, čo bolo potvrdené aj testom RTOR vyššie. Potvrdené bolo aj hypotetizované poradie typov RIASEC v modeli. V modeli je však niekol'ko odlišností. Typ $R$ sa nachádzal vo väčšej vzdialenosti od ostatných typov, ako bolo predpokladané. Zároveň typy $\mathrm{C}$ a I sa nachádzali bližšie k sebe ako bolo predpokladané.

\section{DISKUSIA}

Ked’že má predkladaná štúdia exploračnú povahu, a zároveň v domácich podmienkach nebola realizovaná obdobná analýza, neboli ani apriórne formulované hypotézy zamerané na potvrdenie platnosti niektorého $\mathrm{z}$ overovaných štruktúrnych modelov. Výsledky súvisiace s potvrdením platnosti Hollandovho kruhového modelu ako najlepšieho z troch testovaných 
modelov pre vysvetlenie štruktúry profesijných záujmov žiakov končiacich ročníkov základných škôl sú diskutované nižšie.

S ciel'om charakterizovat' výskumnú vzorku boli overované aj rodové rozdiely v profesijných záujmoch. Zistené vel'ké vel'kosti efektu pre silnejšie praktické záujmy u chlapcov a silnejšie sociálne a umelecké záujmy u dievčat a malý efekt pre intelektuálne záujmy v prospech chlapcov sú v súlade so zisteniami iných autorov (Murray \& Hall, 2001; Proyer \& Häusler, 2007; Su, Rounds, \& Armstrong, 2009; Super \& Crites, 1962). Tieto rozdiely sú najčastejšie vysvetl'ované rodovo špecifickou výchovou. Zistené malé vel'kosti efektu pre silnejšie konvenčné záujmy pre chlapcov a silnejšie podnikatel'ské záujmy u dievčat je možné vysvetlit' analýzou položiek v DŠVZ. Položky pre podnikatel'ské záujmy (napr. niekomu niečo predávat'; jednat' s inými l'ud'mi) viac korešpondujú so sociálnym zameraním a položky pre konvenčné záujmy (napr. pracovat's počítacím strojom, s počítačom; predmety, materiály usporadúvat' alebo spravovat') s praktickým zameraním.

Z troch testovaných modelov, Hollandovho (1997) kruhového modelu, Gatiho (1979) hierarchického modelu a Roundsovho a Traceyho (1996) modifikovaného hierarchického modelu bol pomocou randomizačného testu hypotetických poradí identifikovaný ako najlepší pri vysvetlení štruktúry profesijných záujmov Hollandov (1997) model. Z indexu zhody =.638 vyplýva, že $81.9 \%$ predikcií bolo v súlade s údajmi. Výsledok korešponduje s priemerným CI $=.50$ a SD $=.19$ Hollandovho kruhového modelu, ktorý zistili Rounds a Tracey (1996) v metaanalýze 96 štúdií realizovaných do roku 1996. Takýto „,nedokonalý“ výsledok je podl'a Šverka a Babarovića (2006) pochopitel'ný, ked’že v tak mladom veku ešte nie je možné očakávat' u žiakov stabilné záujmy, preto sa aj štruktúra záujmov bude vekom postupne podobat' viac a viac kruhovému modelu. $Z$ krajín kultúrne i geograficky najviac príbuzných bol model fit Hollandovho kruhového modelu potvrdený napr. v Srbsku (Hedrih, 2008, CI = .93), v Bulharsku (Hedrih, Stošic, Simic, \& Ilieva, 2016, CI = .94, .90) alebo v Nemecku (Nagy, Trautwein, \& Lüdtke, 2010, CI = .79).

Pomocou multidimenzionálneho škálovania uskutočneného na údajoch z celej vzorky bolo potvrdené kruhové usporiadanie RIASEC typov, avšak nie hexagonálne usporiadanie. Takýto výsledok nie je podl'a samotného autora modelu, Hollanda (1979, in Rounds \& Zevon, 1983, s. 495), prekvapujúci, nakol'ko usporiadanie typov v reálnych údajoch sa iba málokedy podobá dokonalému šest'uholníku. Tento nedokonalý šest'uholník pomenoval Holland ako „misshapened polygon“. Rounds a Zevon (1983) uvádzajú, že kruhové usporiadanie naprieč rôznymi výskumami je bežné, avšak hexagonálne usporiadanie je potvrdené iba vel'mi zriedkavo. Tracey a Rounds (1993) v neskoršej metaanalýze potvrdili kruhové usporiadanie typov RIASEC, avšak na vzorke bielych anglicky hovoriacich Američanov, a preto rovnako nastol'ujú otázku ohl'adom adekvátnosti kruhového modelu v iných kultúrach. Potvrdzujú to aj zistenia na európskych vzorkách (Einarsdóttir, Rounds, Aegisdóttir, \& Gerstein, 2002; Sidiropoulou-Dimakakou, Mylonas, \& Argyropoulou, 2008), ktoré síce zistili usporiadanie RIASEC, ale niektoré typy neboli diferencované alebo sa nachádzali vo väčšej vzdialenosti od ostatných. Tieto odlišnosti od Hollandovho modelu je možné podl'a autorov Haverkamp, Collins a Hansen (1994) vysvetlit' aj tak, že štruktúra záujmov nie je univerzálna, ale častokrát je formovaná aj kultúrnym prostredím a etnickou príslušnost'ou osoby. Je vhodné uviest', že potvrdenie platnosti Hollandovho (1997) modelu predpokladá zároveň potvrdenie platnosti Predigerovho modelu bipolárnych faktorov (Veci-L’udia, Myšlienky-Údaje), ked’že 
z Predigerovho modelu nevyplývajú podl'a Roundsa a Traceyho (1993) žiadne predikcie, ktoré by boli protichodné s Hollandovym modelom.

\section{ZÁVER}

Hollandove typy osobnosti a prostredia RIASEC umožňujú nielen poznávat', ale aj predpovedat' vol'bu povolania konkrétnej osoby, jej spokojnost' v zamestnaní, profesijnú stabilitu a úspech, vol'bu štúdia, študijný úspech, kvalifikovanost' či sociálne správanie (Holland, 1973, 1997). Podl'a citovaného autora môže hexagonálny model slúžit' trom hlavným účelom: 1) Definuje stupeň konzistencie v osobnostnej skladbe. Profil osobnostnej skladby zložený zo susediacich typov v hexagonálnom modeli je najviac konzistentný (napr. realistický-intelektuálny typ). Profil osobnostnej skladby zložený z protil'ahlých typov v hexagonálnom modeli je konzistentný najmenej; 2) Definuje konzistenciu prostredia rovnakým spôsobom ako v predošlom bode a 3) Definuje stupeň kongruencie medzi osobou a jej prostredím. Najkongruentnejšou kombináciou napríklad pre sociálny typ by bolo sociálne prostredie. Najmenej kongruentnou kombináciou by pre túto osobu bolo praktické prostredie.

Armstrong, Day, McVay a Rounds (2008) uvádzajú, že vnímanie toho, ktoré pracovné prostredie bude pre jedinca vhodné a dobré, je často vyjadrené cez záujmy, a preto meranie záujmov je základným kameňom poradenstva pri vol'be povolania. Osobnostný typ, ktorý je dominantný u osoby, determinuje aj hlavný smer jej profesijnej vol'by. Je pravdepodobné, že osoba s dominantným typom R si zvolí aj niektorú z profesií spadajúcu pod typ R (napríklad automechanik, elektrotechnik, vojak, policajt a pod.). Využitie hexagonálneho modelu vidia Armstrong et al. (2008) v práci poradcu pre vol'bu povolania, ktorý je schopný pomocou využitia tohto modelu predpovedat', ktoré kategórie profesií sa javia byt' kongruentné pre určitú osobu, vypočítat' konzistenciu osobnostného profilu osoby a konzistenciu medzi osobou momentálne zvolenou a jej profilom záujmov získaným pomocou záujmového inventára.

K silným stránkam prezentovaného výskumu patrí to, že sa podl’a našich vedomostí jedná o prvé skúmanie štruktúry záujmov žiakov tohto druhu na Slovensku a v Českej republike. Ako už bolo spomenuté vyššie, poznanie štruktúry záujmov je predpokladom pre vhodný výber, použitie i interpretáciu záujmových dotazníkov. Ďalšou silnou stránkou je, že testovaným modelom nebol iba jeden, ale tri najznámejšie modely RIASEC. K slabým stránkam výskumu patrí úzke vekové ohraničenie a nereprezentatívnost' vzorky. Avšak, vzhl'adom k povahe testov, štatistickej významnosti všeobecne a s tým súvisiacich odlišných distribúcií p-hodnôt - pri platnosti nulovej alebo alternatívnej hypotézy - by bolo nutné dané zistenia overit' na d'alších vzorkách aj $\mathrm{v}$ rámci reprezentatívnej vzorky. Len takýmto spôsobom je možné potvrdit' existenciu fenoménu, v našom prípade platnost' Hollandovho modelu. Tento predpoklad sa odráža aj v požiadavke replikovatel'nosti vedeckých zistení. Do d'alšieho výskumu je možné odporúčat' nielen testovanie uvedených modelov, ale aj d'alšieho známeho štruktúrneho modelu, gul'ového modelu od Traceyho a Roundsa (1996), ktorý však nenadväzuje na koncepciu RIASEC. S tým súvisí aj potreba adaptovat' dotazník PGI (Personal Globe Inventory), ktorý pochádza od uvedených autorov a namiesto šiestich záujmových kategórií predpokladá existenciu ôsmich kategórií - teda záujmových typov. 
Záverom možno zhrnút', že z troch testovaných modelov vysvetlil najlepšie štruktúru záujmov slovenských žiakov zist'ovanú prostredníctvom Dotazníka štruktúry všeobecných záujmov (Džuka, 1999) - kruhový model Hollanda (1997). Preto možno tento dotazník odporúčat' ako vhodný nástroj s overenou teoretickou štruktúrou nielen pre výskumníkov, ale rovnako aj pre praktikov, ktorí sa venujú profesijnej orientácii a poradenstvu pri vol’be povolania, najmä v rámci 1. smerovej vol’by.

\section{Pod'akovanie}

Táto štúdia bola realizovaná s podporou agentúry VEGA, číslo projektu 1/0610/16.

\section{Literatúra}

Armstrong, P. I., Day, S. X., McVay, J. P., \& Rounds, J. (2008). Holland's RIASEC model as an integrative framework for individual differences. Journal of Counseling Psychology, 55(1), 1-18. doi: 10.1037/0022-0167.55.1.1

Dunn, T. J., Baguley, T., \& Brunsden, V. (2014). From alpha to omega: A practical solution to the pervasive problem of internal consistency estimation. British Journal of Psychology, 105(3), 399412.doi:10.1111/bjop.12046

Džuka, J. (1999). Konštruktová validita dotazníka štruktúry všeobecných záujmov (DŠVZ). Československá psychologie, 43(2), 143-154.

Einarsdóttir, S., Rounds, J., Aegisdóttir, S., Gerstein, L. H. (2002). The structure of vocational interests in Iceland: Examining Holland's and Gati's RIASEC models. European Journal of Psychological Assessment, 18(1), 85-95. doi:10.1027//1015-5759.18.1.85

Gati, I. (1979). A hierarchical model for the structure of vocational interests. Journal of Vocational Behavior, 15(1), 90-106. doi:10.1016/0001-8791(79)90021-6

Gati, I. (1991). The structure of vocational interests. Psychological Bulletin, 109(2), 309-324. doi: 10.1037/e345912004-001

Haverkamp, B. E., Collins, R. C., \& Hansen, J. C. (1994). Structure of interests of AsianAmerican college students. Journal of Counseling Psychology, 41(2), 256-264. doi:10.1037/00220167.41.2.256

Hedrih, V. (2008). Structure of vocational interests in Serbia: Evaluation of the spherical model. Journal of Vocational Behavior, 73(1), 13-23. doi:10.1016/j.jvb.2007.12.004

Hedrih, V., Stošic, M., Simic, I., \& Ilieva, S. (2016). Evaluation of the hexagonal and spherical model of vocational interests in the young people in Serbia and Bulgaria. Psychologija, 49(2), 199-210. doi:10.2298/psi1602199h

Holland, J. L. (1973). Making vocational choices: A theory of careers. New Jersey: PrenticeHall, Inc.

Holland, J. L. (1997). Making vocational choices: A theory of vocational personalities and work environments. Third edition. PAR: Psychological Assessment Resources, Inc.

Holland, J. L., \& Messer, M. A. (2013). Self-Directed Search: Professional Manual. PAR: Lutz, Florida.

Hubert, L., \& Arabie, P. (1987). Evaluating order hypotheses within proximity matrices.

Psychological Bulletin,102(1), 172-178. doi: 10.1037//0033-2909.102.1.172 
Machajová, Z., \& Sojčák, A. (2011). Kariérové poradenstvo v podmienkach CPPPaP. Výsledky celoslovenského prieskumu. In Š. Matula (Ed.), Kariérové poradenstvo v rezorte školstva a jeho interdisciplinárne súvislosti - tradícia, aktuálny stav, perspektivy. Zborník príspevkov z II. poradenských dní v Slovenskej republike s medzinárodnou účast'ou. Dolný Kubín, 23.-25. marec. Murray, J. L., \& Hall, P. M. (2001). Gender differences in undergraduate Holland personality types: Vocational and cocurricular implications. NASPA Journal, 39(1), 14-29. doi:10.2202/00276014.1157

Nagy, G., Trautwein, U., \& Lüdtke, O. (2010). The structure of vocational interests in Germany: Different methodologies, different conclusions. Journal of Vocational Behavior, 76(2), 153-169. doi:10.1016/j.jvb.2007.07.002

Prediger, D. J. (1982). Dimensions underlying Hollands hexagon: Missing link between interests and occupations? Journal of Vocational Behavior, 21(3), 259-289. doi: 10.1016/00018791(82)90036-7

Prieskum metodik zistovania profesijných záujmov (n.d.). Výskumný ústav detskej psychológie a patopsychológie. Dostupné na

http://www.vudpap.sk/sub/vudpap.sk/images/pdf/Prieskum_metodik.pdf

Proyer, R. T., \& Häusler, J. (2007). Gender differences in vocational interests and theirstability across different assessment methods. Swiss Journal of Psychology, 66(4), 234-237. doi: 10.1024/1421-0185.66.4.243

$\mathrm{R}$ Core Team. (2017). R: A language and environment for statistical computing. R Foundation for Statistical Computing: Vienna, Austria. URL https://www.R-project.org/.

Rounds, J. B., \& Day, S. X. (1999). Describing, evaluating and creating vocational interest structures. In M. L. Savickas \& A. R. Spokane (Eds.), Vocational interests: Meaning, measurement and counselling use (pp. 103-133). Palo Alto, CA: Davies Black.

Rounds, J. B., \& Tracey, T. J. (1993). Prediger's Dimensional Representation of Holland's RIASEC Circumplex. Journal of Applied Psychology, 78(6), 875-890. doi:10.1037/00219010.78.6.875

Rounds, J. B., Tracey, T. J., \& Hubert, L. (1992). Methods for evaluating vocational interest structural hypotheses. Journal of Vocational Behavior, 40(2), 239-259. doi:10.1016/00018791(92)90073-9

Rounds, J. B., \& Zevon, M. A. (1983). Multidimensional scaling research in vocational psychology. Applied Psychological Measurement, 7(4), 491-510.

doi:10.1177/014662168300700407

Savickas, M. L., \& Gottfredson, G. D. (1999). Holland's theory (1959-1999): 40 years of research and application. Journal of Vocational Behavior, 55(1), 1-4. doi:10.1006/jvbe.1999.1694

Sidiropoulou-Dimakakou, D., Mylonas, K., \& Argyropoulou, K. (2008). Holland's hexagonal personality model for a sample of Greek university students. International Journal for Educational and Vocational Guidance, 8(2), 111-125. doi:10.1007/s10775-008-9141-0

Spokane, A. R., \& Holland, J. L. (1995). The Self-Directed Search: A family of self-guided career interventions. Journal of Career Assessment, 4(3), 373-390. doi:10.1177/106907279500300409

Su, R., Rounds, J., \& Armstrong, P. I. (2009). Men and things, women and people: A metaanalysis of sex differences in interests. Psychological Bulletin, 135(6), 859-884.

doi:10.1037/a0017364 
Super, D. A., \& Crites, J. O. (1962). Appraising vocational fitness: by means of psychological tests. New York a Evanston: Harper a Row Publishers.

Šverko, I., \& Babarović, T. (2006). The validity of Holland's theory in Croatia. Journal of Career Assessment, 14(4), 490-507. doi:10.1177/1069072706288940

Tracey, T. J. G. (1997). RANDALL: A Microsoft FORTRAN program for a randomization test of hypothesized order relations. Educational and Psychological Measurement, 57(1), 164-168. doi:10.1177/0013164497057001012

Tracey, T. J. G. (2002). Personal Globe Inventory: Measurement of the spherical model of interests and competence beliefs. Journal of Vocational Behavior, 60(1), 113-172. doi:10.1006/jvbe.2001.1817

Tracey, T. J., \& Rounds, J. (1993). Evaluating Holland's and Gati's vocational interest models: A structural meta-analysis. Psychological Bulletin, 113(2), 229-246. doi:10.1037/0033-

2909.113.2.229

Tracey, T. J. G., \& Rounds, J. (1996). The spherical representation of vocational interests. Journal of Vocational Behavior, 48(1), 3-41. doi: 10.1006/jvbe.1996.0002

Tracey, T. J. G., \& Ward, C. C. (1998). The structure of children's interests and competence perceptions. Journal of Counseling Psychology, 45(3), 290-303. doi:10.1037/0022-0167.45.3.290

Wagenaar, W. A., \& Padmos, P. (1971). Quantitative interpretation of stress in Kruskal's multidimensional scaling technique. British Journal of Mathematical and Statistical Psychology, 24(1), 101-110. doi:10.1111/j.2044-8317.1971.tb00452.x

\section{Údaje o autoroch:}

Mgr. Marcel Martončik, PhD. je odborným asistentom na Inštitúte psychológie Filozofickej fakulty Prešovskej univerzity v Prešove. Výskumne sa venuje psychologickým aspektom hrania počítačových hier ale aj problematike profesijných záujmov a dôsledkom chudoby na kognitívne funkcie osôb.

\section{Kontaktné údaje:}

Adresa: Inštitút psychológie FF PU V Prešove, U1. 17. novembra 1, 08001 Prešov

E-mail: martoncik@protonmail.ch

PhDr. Monika Kačmárová, PhD. je odbornou asistentkou na Inštitúte psychológie Filozofickej fakulty Prešovskej univerzity $\mathrm{v}$ Prešove. Participuje na výskumoch zaoberajúcich sa psychologickými dôsledkami chudoby, a tiež profesijnou orientáciou žiakov základných škôl. Venuje sa tiež skúmaniu subjektívnej pohody, kvality života a témam z oblasti školskej a poradenskej psychológie.

\section{Kontaktné údaje:}

Adresa: Inštitút psychológie FF PU V Prešove, U1. 17. novembra 1, 08001 Prešov

E-mail: monika.kacmarova@unipo.sk

Martončik, M., \& Kačmárová, M. (2018). Štruktúra profesijných záujmov slovenských žiakov základných škôl na báze modelov RIASEC. E-psychologie, 12(2), 16-26.

https://doi.org./10.29364/epsy.317 